\title{
Chapter 8 \\ The Effect of Person-Organization Fit on Work Engagement and Performance
}

\begin{abstract}
Perceived organizational fit as perceived by employees can function as an important distal organizational resource, which has motivational potential and can foster employee's work engagement. Based on the theoretical lens, this study examines mechanisms that can explain the motivational potential that the organizational environment and personal resources might have at both the individual as the team level.
\end{abstract}

Keywords Organizational fit • P-O fit theory • Performance indicators • Sustainable performance

\subsection{Introduction}

It seems that the importance of physical and mental vigor for professional and organizational development is clear. But we should not underestimate the importance of a good fit with the corporate culture, as many other studies show (Kristof 1996; Kristof-Brown et al. 2002; Taris 2003). My fifth hypothesis was as follows:

Hypothesis 5 Having a good fit with the organization to a greater or a lesser degree positively or negatively influences the relationship between talent and performance.

Many scientists and authors support this hypothesis. Take Kristof-Brown and Taris, for instance, who have put the importance of person-organization fit (P-O fit) on the scientific map (Fig. 8.1).

Their P-O fit studies are based on the idea that individuals are increasingly interacting with their environment, and that employee behavior is influenced and directed by both environment factors and personality traits. The current interest in P-O fit studies can also be explained through the fact that several researchers, including the aforementioned Kristof (1996) and Taris (2003) are finding conformation for the assumption that a high degree of fit of the employee with his environment, has a positive effect on both his own performance and that of the organization. But what aspects determine whether an employee has a good fit with an organization? And to what extent are these elements on their own important for sustainable performance? 


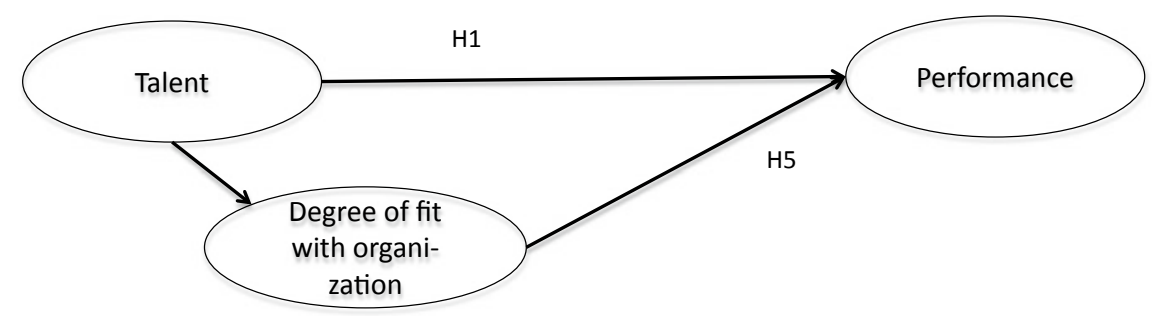

Fig. 8.1 Hypothesis 5

\subsection{Fit with Job and Supervisor}

The Interaction Processing meta-theory by Ehrhart and Ziegert (2005) describes how and why the attractiveness of organizations is influenced. This theory is basically a framework for all theories that argue that the fit between personal and environmental characteristics makes organizations more attractive for employees. In the literature, this fit is called the Person-Environment Fit (P-E fit).In a broader sense, P-E fit can be defined as the match between the values, goals, and personality of an individual and those of that person's environment (Kristof-Brown et al. 2002).

The term "environment" in the definition of P-E fit above, is a very wide-ranging concept. It is therefore important to split up "environment" into different domains (Kristof-Brown et al. 2002). The Person-Job Fit is about the match between a person and his or her job, just like P-O fit is about a person and the culture of the organization he or she works for. Finally, there is also a Person-Supervisor Fit. In my study, I used the following important selection criteria: a good fit with the job and the culture of the organization and supervisor. At the end of this chapter, I will discuss the results individually.

\subsection{Organizational Culture and Change}

How important is organizational culture? And to what extent does a good fit with the organizational culture determine sustainable performance? The most famous management authors on these topics are probably Cameron and Quinn (2011). Kim Cameron is a professor of management and organization at the University of Michigan. His studies on organizational performance, corporate culture, and the development of leadership have resulted in over 120 articles and 14 books. His most recent study is aimed at the positive dynamic that leads to improved performance in organizations. As an instructor and researcher, he is mostly interested in organizational change and effectiveness. Robert Quinn is associated with the Graduate School of Business of the University of Michigan. He is internationally recognized as the leading authority in the field of change management. Quinn's research and education are aimed at change and effectiveness in organizations. He is mostly known for his 
Competing Values Framework (the Quinn model), which is considered to be one of the most important models in the history of the business.

According to Cameron and Quinn, no twenty-first century organization should be proud of being consistent, remaining unchanged, and still being in the same position it was a decade earlier. They believe stability is more a form of stagnation than a goal of equanimity or as Billy Beane put it: "No matter how successful you are, change is always good."

Yet most planned organizational changes fail at an alarming rate. According to several studies on organizational change, up to three-quarters of all attempts fail completely, in many cases threatening the survival of the organization. However, what is interesting about these failures, according to Cameron and Quinn, are the causes that have been cited for the lack of success. Several studies show that disregarding organizational culture was most often identified as the cause of failure (Cameron and Quinn 2011).

\subsection{Conditions for Success}

A significant amount of the somewhat dated literature indicates that successful businesses - those that continually make a profit and achieve above-average turnoverneed to meet at least several of the following clearly described conditions (Cameron and Quinn 2011):

1. High barriers to entry for new entrants;

2. Unique products;

3. Having a large market share;

4. Limited bargaining power of customers;

5. Limited bargaining power of suppliers;

6. Significant rivalry between competitors (instead of towards your organization).

This makes it all the more remarkable that the most successful American businesses-and I expect the situation in Europe and the Netherlands will not be all that different - of the past thirty years had none of these competitive advantages (Cameron and Quinn 2011). Of the best-performing businesses of the past three decades - the ones that completely outperformed the competition-none met even one of the previously mentioned conditions for success.

Apple, which nearly went bankrupt in 1998, is one of the five most valuable companies in the world, worth more than Microsoft. Apple entered a market that was dominated by established and highly competitive companies such as Microsoft, Motorola, Nokia, IBM, and Dell. The same was true for animation studio Pixar, which entered a market that had long been dominated by Disney. In less than 30 years of its existence, the company scored 11 hit movies out of 11 attempts. This was completely unheard of in the movie industry. Every movie Pixar has made has been nominated for an Oscar. It won the award in three out of every four cases. Cameron and Quinn (2011), but also scientists like Taris (2003) and Kristof-Brown (2005), 
indicate that it is the fit with an organization, its culture, and style that determines sustainable performance. Organizations with a strong culture and employees that suit it have the greatest chance to survive according to the aforementioned scientists.

But how important is a good fit with the organization and the organizational culture really? To what extent is a good fit with their immediate supervisors important for the performance of professionals?

In this study, organizational culture was defined as the collection of norms, values, and behavior that is shared by the organization's members, and that connects the members to each other and the organization.

\subsection{Results of the Study}

Realizing and maintaining a culture of performance with the right principles, norms, and values are vital to sustainable performance. Studies confirm this again and again. According to scientists Cameron and Quinn, these aspects are in fact the most important factor for the success or failure of any organization (Cameron and Quinn 1998, 2011). Without a fitting culture, that is embraced and reinforced by every new hire, the work effectiveness of the organization will quickly diminish, eventually leading to the organization's downfall.

The outcomes of this study also confirm this statement. The overall concept of Organization Fit (fit with the culture and supervisor) showed a very strong and significant correlation to performance (also see Appendices C and D: Correlation Matrix Factors). The results of this study did not specifically indicate that a fit with the organizational culture is the most important performance criterion. A good fit with the supervisor scored much higher as a performance predictor.

It turns out that sustainable performance is significantly influenced not just by organizational culture, but also by the way a team is managed by its supervisor. People make decisions for, perform for, and leave because of other people, it seems. Getting along with one's supervisor appears to be essential for sustainable performance.

\section{References}

Cameron KS, Quinn RE (1988) Paradox and transformation: toward a theory of change in organization and management. Eds. Cambridge, MA, Ballinger

Cameron KS, Quinn RE (2011) Onderzoeken en veranderen van organisatiecultuur (3rd revised edition). Academic Service, The Hague

Ehrhart KH, Ziegert JC (2005) Why are individuals attracted to organizations? J Manag 31(6):901919

Kristof AL (1996) Person-organization fit: an integrative review of its conceptualizations, measurement and implications. Personn Psychol 49(1):1-49 
Kristof-Brown AL, Jansen KJ, Colbert AE (2002) A policy-capturing study of the simultaneous effects of fit with jobs, groups and organizations. J Appl Psychol 87(5):985-993

Taris R (2003) Person-environment fit. A longitudinal study of the interaction between employee characteristics and work environmental characteristics. Ridderprint Offsetdrukkerij, Ridderkerk

Open Access This chapter is licensed under the terms of the Creative Commons Attribution 4.0 International License (http://creativecommons.org/licenses/by/4.0/), which permits use, sharing, adaptation, distribution and reproduction in any medium or format, as long as you give appropriate credit to the original author(s) and the source, provide a link to the Creative Commons license and indicate if changes were made.

The images or other third party material in this chapter are included in the chapter's Creative Commons license, unless indicated otherwise in a credit line to the material. If material is not included in the chapter's Creative Commons license and your intended use is not permitted by statutory regulation or exceeds the permitted use, you will need to obtain permission directly from the copyright holder.

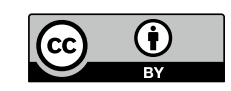

